\title{
STUDY OF PRECIPITATING METHODS FOR ELIMINATION OF HEAVY METALS FROM ACID MINE DRAINAGE
}

\author{
ALENA LUPTÁKOVÁ ${ }^{1}$, STEFANO UBALDINI ${ }^{2}$, \\ EVA MAČINGOVÁ ${ }^{1}$, INGRIDA KOTULIČOVÁ ${ }^{1}$ \\ ${ }^{1}$ Institute of Geotechnics of Slovak Academy of Sciences, Watsonova 45, Košice, \\ SK-043 53, Slovak Republic (luptakal@saske.sk) \\ ${ }^{2}$ Institute of Environmental Geology and Geoengineering, CNR, Roma, Italy \\ (stefano.ubaldini@igag.cnr.it)
}

\begin{abstract}
The submitted paper deals with the study of combination of chemical and biological-chemical methods for the heavy metals elimination from the acid mine drainage. The experiments were carried out at the laboratory scale using a synthetic solution with similar properties to the real sample of acid mine drainage, originating from the zinc mine located in Tùnel Kingsmill outflow of the Rio Yaulì (district of Yauli - Perù). The successive repetition of the metal precipitations as hydroxides (chemical method) and sulphides (biological-chemical method) at the various acid mine drainage $\mathrm{pH}$ was the basis of the examined processes. For the hydrogen sulphide production the sulphate-reducing bacteria of genus Desulfovibrio were used. Results confirmed the precipitation of Fe, As, $\mathrm{Al}$ and $\mathrm{Mn}$ in the hydroxide form; $\mathrm{Cu}$ and $\mathrm{Zn}$ in the form of sulphides. For the selective removal of $\mathrm{Cu}, \mathrm{Zn}, \mathrm{Al}$ and $\mathrm{Mn}$ the excellent results were received. Selective precipitation of $\mathrm{Fe}$ and $\mathrm{As}$ was not so successful since the co-precipitation of $\mathrm{Fe}$ and As was later determined as a main mechanism of the precipitate forming.
\end{abstract}

Keywords: acid mine drainage, metals, selective sequential precipitation

\section{Introduction}

Acid mine drainage (AMD) represents the major environmental problem especially associated with mining activities. The basis of the AMD generation is the oxidation of pyrite and other sulphidic minerals exposed to both oxygen and water. Each AMD has a specific composition, but always contains high concentration of the sulphuric acid, dissolved heavy metals, sulphates, iron precipitates and their $\mathrm{pH}$ values can be very low. Consequently AMD must be collected and treated before it can be discharged (YOUNGER et al., 2002; KADUKOVA and STOFKO, 2009).

Various methods are used for the treatment of AMD but any of them have not been applied under the commercial-scale. Chemical and biological-chemical methods are mostly studied with the aim to eliminate metals, sulphates and achievement the neutral pH (PRASCAKOVA, 2005; KAKSONEN and PUHAKKA, 2007; JENCAROVÁ, 2008; KAVULICOVA et al., 2009; IVANOVA et al., 2010). In general two strategies - active and passive technologies - for treating AMD are used: (SKOUSEN et al., 1998; BALINTOVA and LUPTAKOVA, 2012). In the conventional treatment system alkaline materials and other chemicals are added to the AMD to neutralize it and enhance hydroxide precipitation. Gradually the $\mathrm{pH}$ increases and the metal ions precipitation (for example as hydroxides) are achieved. Each metal in aqueous solution contributes to the AMD acidity. Additionally, individual metals precipitate at specific 
$\mathrm{pH}$ levels. For example, hydroxides of $\mathrm{Fe}^{3+}$ precipitate at about $\mathrm{pH} 3$ and of $\mathrm{Al}^{3+}$ at $\mathrm{pH}$ ranging from 3.7 to 4.5 . Divalent metal ions precipitate in the alkaline range, $\mathrm{Ni}^{2+}$ at about $\mathrm{pH} 8, \mathrm{Fe}^{2+}$ at $\mathrm{pH}$ ranging from 8 to 9 and $\mathrm{Zn}^{2+}$ at more than $\mathrm{pH} 9$ (SKOUSEN et al., 1998). The precipitation process is affected not only by reaction time but also by the thermodynamic considerations. The general importance of $\mathrm{pH}$ in an AMD system is not the only important factor in metal removal but also ionic strength, temperature, redox potential, and concentrations of suitable complexing agents (e.g. humic substances) and interactions of the precipitated solids play a significant role. The treatments using alkaline materials involve some serious limitations of application and effectiveness. They usually result in production of unstable metal hydroxides mixture, also leading to a greater disposal expense. The high operating costs and production of a bulky sludge, which must be disposed, are the disadvantages of the traditional chemical treatment.

The research and development of the appropriate combinations of the chemical and biological-chemical methods for the metals selective recovery from AMD suggested the interesting solution of problems concerning the AMD treatment. These methods constitute the possibility of metals recovery in a suitable form for commercial or industrial utilization. The combination of the metal precipitation using the sodium hydroxide (chemical methods) and metal precipitation using the bacterially produced hydrogen sulphide (biological-chemical method) presents the base of the selective sequential precipitation (SSP) (TABAK et al., 2003). The base of SSP is the evidence that metals in aqueous solution precipitate by addition of sodium hydroxide solution or hydrogen sulphide at specific $\mathrm{pH}$ levels. The acid-base titration by the sodium hydroxide solution is a simple and convenient method for the suitable $\mathrm{pH}$ determination of the metals selective precipitation from aqueous solution. The issue of alkalimetry is the titration curve (the vertical part shows the process $\mathrm{OH}^{-}$ions neutralizing $\mathrm{H}^{+}$ions; the horizontal part indicates $\mathrm{OH}^{-}$ions precipitating metal ions into metal hydroxides, which will act as a buffer keeping the constant $\mathrm{pH}$ for the short time until the specific metal will completely precipitate). When $\mathrm{pH}$ reaches at the certain level the metal ions will precipitate and be eliminated from the water. SSP is the environmentally friendly way for the metals and metalloids elimination from AMD.

The main objective of the paper was to interpret the SSP process that is the combination of chemical and biological-chemical methods as a way of chosen metals ( $\mathrm{Fe}, \mathrm{As}, \mathrm{Cu}, \mathrm{Al}, \mathrm{Zn}$ and $\mathrm{Mn}$ ) separation from the model solution of Peruvian AMD.

\section{Materials and methods}

\subsection{Synthetic solution of acid mine drainage}

The experiments were carried out at the laboratory scale using a synthetic solution of AMD coming from the zinc mine located in Tùnel Kingsmill outlet of the Rio Yaulì (district of Yauli - Perù). The synthetic solution with the similar properties to the real sample of AMD was prepared. Reagents with a high analytical degree of purity were used (RPE Carlo Erba). Based on the metal concentrations in the real AMD sample, 
the model solution with the same metal concentrations was prepared. The corresponding salts were weighed and dissolved in deionized water. The solution $\mathrm{pH}$ value was adjusted to 3 using $5 \mathrm{M} \mathrm{NaOH}$. A little amount of $\mathrm{H}_{2} \mathrm{O}_{2}$ was added to the synthetic solution with the aim to get $\mathrm{Fe}, \mathrm{As}$ and $\mathrm{Mn}$ in the form of $\mathrm{Fe}^{3+}, \mathrm{As}^{5+}$ and $\mathrm{Mn}^{2+}$. The annual average metals concentration of Peruvian AMD is outlined in Table 1.

Table 1. Concentration of chosen elements of AMD sample from Perù with the annual average pH value 3.1.

\begin{tabular}{cccccccccc}
\hline Element & Al & Cd & $\mathbf{C u}$ & Zn & As & Mn & Fe & Ca & Mg \\
\hline $\begin{array}{c}\text { Concentration } \\
\text { (mg. }^{-1} \text { ) }\end{array}$ & 7.80 & 0.16 & 10.80 & 69.15 & 1.96 & 62.35 & 127.86 & 381 & 49.50 \\
\hline
\end{tabular}

\subsection{Chemical and biological-chemical methods combination}

The successive repetition of the metal precipitation as hydroxides (chemical method) and sulphides (biological-chemical method) at the acid mine drainage various $\mathrm{pH}$ were the fundamental of the examined processes. This selective sequential precipitation (SSP) was realized in two principal steps: 1 - addition of $0,2 \mathrm{M} \mathrm{NaOH}$ solution by the automatic titrator TitraLab $850 ; 2$ - addition of bacterially produced $\mathrm{H}_{2} \mathrm{~S}$ by the nitrogen gas continuous transfer from the cultivation tank. The determination of suitable $\mathrm{pH}$ values for selective precipitation of metals from studied model solution was performed in the previous experiments by the acid-base titration alkalimetry using automatic titrator TitraLab 850 in connection with PC program TitraMaster 85. The strains of SRB (genus Desulfovibrio) were used for the hydrogen sulphide production. Bacteria were isolated from the potable mineral water (LUPTAKOVA et al., 2002; MACINGOVA, 2010). At the end of SSP respective steps the formed precipitates of the individual metals were removed by filtration from the AMD solution. In the filtrates the metal concentrations were analysed by atomic absorption spectrometry (AAS).

\section{Results and discussions}

Table 2 illustrates particular steps of the experimental procedure and obtained results of the selective sequential precipitation of heavy metals from the AMD synthetic solution.

Table 2. Metals precipitation by $\mathrm{NaOH}$ and bacterially produced $\mathrm{H}_{2} \mathrm{~S}$.

\begin{tabular}{|c|c|c|c|c|c|}
\hline & 1-Step & 2-Step & 3-Step & 4-Step & 5-Step \\
\hline $\mathrm{pH}$ & $3.0 \rightarrow 4.5$ & $4.5 \rightarrow 3.9$ & $3.9 \rightarrow 5.8$ & $5.8 \rightarrow 5.0$ & $5.0 \rightarrow 10.5$ \\
\hline Precipitating agent & $\mathrm{NaOH}$ & $\mathrm{H}_{2} \mathrm{~S}$ & $\mathrm{NaOH}$ & $\mathrm{H}_{2} \mathrm{~S}$ & $\mathrm{NaOH}$ \\
\hline $\begin{array}{l}\text { Removed metals } \\
\text { (precipitates) }\end{array}$ & $\mathrm{Fe}, \mathrm{As}$ & $\mathrm{Cu}$ & $\mathrm{Al}$ & $\mathrm{Zn}$ & $\mathrm{Mn}$ \\
\hline
\end{tabular}

In the 1-Step of process the addition of $0.2 \mathrm{M} \mathrm{NaOH}$ into the AMD solution from initial $\mathrm{pH} 3.0$ to $\mathrm{pH} 4.5$ by the automatic titrator was realized. The addition was 
performed slowly $(0.1 \mathrm{ml} / \mathrm{min})$ and with the solution magnetic agitation. Formation of the orange precipitates was observed at $\mathrm{pH}$ around 3.5. Figure 1 outlines coprecipitation of As and Fe. This behaviour is in accordance with the results of many authors since the arsenic compounds are known to have the high affinity to adsorb on the iron hydroxide (KAKSONEN and PUHAKKA, 2007).

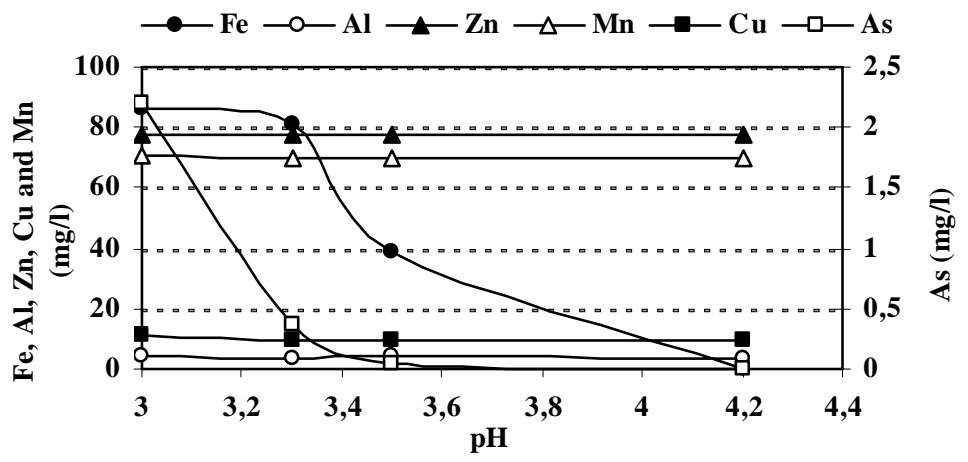

Fig. 1. Co-precipitation of As and Fe during the 1-Step of SSP process.

Bacterially produced $\mathrm{H}_{2} \mathrm{~S}$ was transferred by means of the nitrogen gas continuous flow from the bacteria cultivation tank into the filtrate (after the removal of As and $\mathrm{Fe}$ hydroxides by filtration) (2-Step). This step lasted for 30 minutes. The brown precipitates were observed shortly after 5 minutes. The $\mathrm{pH}$ of AMD solution decreased from 4.5 to 3.9 under the influence of the hydrogen sulphide (KAKSONEN and PUHAKKA, 2007). Cu was probably eliminated in the form of sulphide (Table 3 ).

Table 3. Precipitation of Cu by bacterially produced $\mathrm{H}_{2} \mathrm{~S}$ (2-Step of SSP process)

\begin{tabular}{cccccc}
\hline \multirow{2}{*}{$\begin{array}{c}\text { Time } \\
(\mathrm{min})\end{array}$} & $\mathrm{pH}$ & $\mathrm{Cu}$ & $\mathrm{Zn}$ & $\mathrm{Al}$ & $\mathrm{Mn}$ \\
\cline { 3 - 6 } & & \multicolumn{4}{c}{$\left(\mathrm{mg}^{-1} \mathrm{ml}^{-1}\right)$} \\
\hline 0 & 4.5 & 9.25 & 78 & 3,8 & 70.5 \\
5 & 4.0 & $<0.03$ & 77,9 & 3,9 & 69.9 \\
10 & 3.9 & $<0.03$ & 77,8 & 3,8 & 69.5 \\
15 & 3.8 & $<0.03$ & 77,6 & 3,8 & 69.4 \\
20 & 3.8 & $<0.03$ & 77,9 & 3,7 & 69.6 \\
25 & 3.8 & $<0.03$ & 77,8 & 3,8 & 69.5 \\
30 & 3.9 & $<0.03$ & 77,7 & 3,7 & 69.4 \\
\hline
\end{tabular}

After the removal of $\mathrm{Cu}$ precipitates by filtration, $0.2 \mathrm{M} \mathrm{NaOH}$ solution was added into the filtrate by the automatic titrator until $\mathrm{pH}$ of 5.8 was reached (3-Step). The precipitation of $\mathrm{Al}$ was detected (Fig. 2). White $\mathrm{Al}$ precipitates were obtained after filtration. Bacterially produced $\mathrm{H}_{2} \mathrm{~S}$ was again added into the remaining filtrate (4Step). The white precipitates were observed after 10 minutes. The decrease of AMD solution $\mathrm{pH}$ values from 5.8 to 5.0 was probably due to the influence of the hydrogen sulphide (Table 3). The white precipitates were removed and the last step of the 
process, the addition of $0.2 \mathrm{M} \mathrm{NaOH}$ into the filtrate with consequent $\mathrm{pH}$ increase from 5.0 to 10.5, followed. The precipitation of Mn was identified (Fig. 3.).

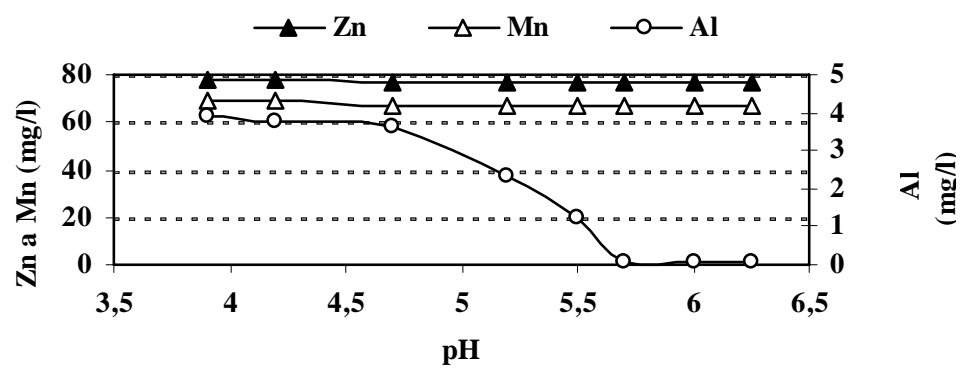

Fig. 2. Precipitation of Al during the 1-Step of SSP process.

Table 4. Precipitation of $\mathrm{Zn}$ by bacterially produced $\mathrm{H}_{2} \mathrm{~S}$ (4-Step of SSP process).

\begin{tabular}{cccc}
\hline \multirow{2}{*}{$\begin{array}{c}\text { Time } \\
(\mathrm{min})\end{array}$} & $\mathrm{pH}$ & $\mathrm{Zn}$ & $\mathrm{Mn}$ \\
\cline { 3 - 4 } & & \multicolumn{2}{c}{$\left(\mathrm{mg} \cdot \mathrm{ml}^{-1}\right)$} \\
\hline 0 & 5.8 & 75.4 & 69.8 \\
5 & 5.4 & 22.6 & 69.6 \\
10 & 5.2 & 0.6 & 69.5 \\
15 & 5.1 & 0.6 & 69.4 \\
20 & 5.0 & 0.6 & 69.6 \\
25 & 5.2 & 0.5 & 69.5 \\
30 & 5.0 & 0.5 & 69.4 \\
\hline
\end{tabular}

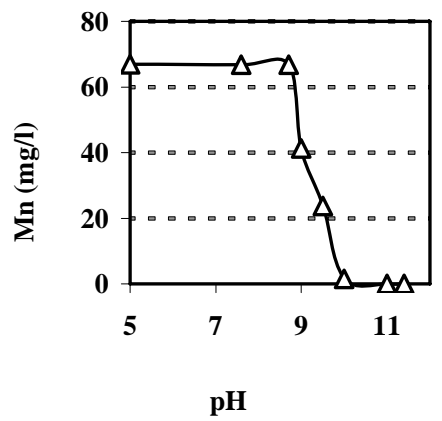

Fig. 3. Precipitation of $\mathrm{Mn}$ during the 5-Step of SSP process.

\section{Conclusions}

The combination of chemical and biological-chemical precipitating methods for the heavy metals elimination from the acid mine drainage was studied. The chemical method was realised by the metal precipitation using the sodium hydroxide and the biological-chemical method using the bacterially produced hydrogen sulphide. Their suitable combination presents the basis of the selective sequential precipitation (SSP). Achieved results demonstrated the possibility of heavy metals removal from the synthetic solution simulating the composition of acid mine drainage coming from the zinc mine located in Tùnel Kingsmill outlet of the Rio Yaulì (district of Yauli - Perù). In SSP process $\mathrm{Fe}^{3+}, \mathrm{As}^{5+}, \mathrm{Al}^{3+}$ and $\mathrm{Mn}^{2+}$ precipitated in the form of hydroxides and $\mathrm{Cu}^{2+}$ and $\mathrm{Zn}^{2+}$ in the form of sulfides. Excellent results were received for the removal of $\mathrm{Cu}, \mathrm{Zn}, \mathrm{Al}$ and $\mathrm{Mn}$. Selective precipitation of $\mathrm{Fe}$ and As was not possible because of the co-precipitation of Fe and As.

Acknowledgements: Work was supported by: Joint Project n.1 of the CNR/SAV (2010/2012); Project CNR RSTL n. 0042.0005; Joint Project n.2 of the CNR/CONCYTEC (Perù) (2009/2011); SRDA-0252-10 and the Scientific Grant Agency No. 2/0166/11. 


\section{References}

BALINTOVA, M., LUPTAKOVA, A.: Treatment of Acid Mine Drainage. Technical University in Kosice, Faculty of Civil Engineering, 2012, 131 pp. ISBN 978-80553-0868-5. (in Slovak)

IVANOVA, D., HORVATHOVA, H., KADUKOVA, J., KAVULICOVA, J.: Stability of immobilized biosorbents and its influence on biosorption of copper. Nova Biotechnol., 10, 2010, 45-51. ISSN 1337-8783.

JENČÁROVÁ, J.: The bacterially preparation of iron sulphides. Acta Metallurg. Slovaca. 14, 2008, 106-109.

KADUKOVA, J., STOFKO, M.: Utilization of Algae for Pollution Elimination, Chapter 5, Algae: Nutrition, Energy Source and Environmental Control (Ed. Kristian N. Hagen), Nova Publishers, New York, 2009, 57-87. ISBN 978-1-60692-008-4.

KAKSONEN, A.H., PUHAKKA, J.A.: Sulfate Reduction Based Bioprocesses for the Treatment of Acid Mine Drainage and the Recovery of Metals, Eng. Life Sci., 7, 6, 2007, 541-564.

KAVULICOVA, J., KADUKOVA, J., PODRACKY, J., IVANOVA, D.: Effect of metals on oxidative stress in Linum Usitatissimum. Proceedings of the $1^{\text {st }}$ International Conference Biotechnology and Metals 2009. Košice, Slovak Republic, September 24-25, 2009, 57-60. ISBN 978-80-553-0236-2

LUPTAKOVA, A., KUSNIEROVA M., FECKO, P.: Mineral biotechnology II. Sulfuretum in nature and industry, VSB -TU Ostrava, Ostrava, Czech Republic, 2002. ISBN 80-248-0114-0.

MACINGOVA, E.: Application possibilities of the bioremediation methods for the elimination of the environmental and industrial loads. Technical University of Košice, Ph.D. thesis, 2010, p.101.

PRASCAKOVA, M.: Adsorption of heavy metals on biologically activated brown coal sludge, Acta Montan. Slovaca, 10, 2005, 161-163.

SKOUSEN, J., ROSE, A., GEIDEL, G., FOREMAN, J., EVANS, R., HELLIER, W.: A Handbook of Technologies for Avoidance and Reclamation of Acid Mine Drainage, West Virginia University, Morgantown, Wv: NMLRC, 1998.

TABAK, H.H., SCHARP, R., BURCKLE, J., KAWAHARA, F.K., GOVIND, R.: Advances in biotreatment of acid mine drainage and biorecovery of metals: Metal precipitation for recovery and recycle. Biodegradation , 14, 2003, 423-436.

YOUNGER, P.L., BANWART, S.A., HEDIN, R.S.: Mine Water: Hydrology, Pollution, Remediation. In: Environmental Pollution, Vol.5, Eds. Alloway, B.J., Trevors, J.T., Kluwer academic Publishers, Dordrecht, Netherlands, 2002.

Presented at the 2nd International Conference "Biotechnology and Metals - 2011", September 22-23, 2011, Košice, Slovak Republic. 